\title{
Microbial Ecology of Pectin Decomposition in Anoxic Lake Sediments
}

\author{
By BERNHARD SCHINK AND J. G. ZEIKUS* \\ Department of Bacteriology, University of Wisconsin, Madison, Wisconsin 53706, U.S.A.
}

(Received 28 May 1981; revised 21 July 1981)

\begin{abstract}
Anaerobic digestion of pectin by bacteria was examined in two freshwater lakes in Wisconsin and in defined laboratory cultures of species prevalent in the lake sediment. The turnover times for pectin biodegradation to methane in sediments incubated at in situ temperature were much longer ( $100 \mathrm{~h}$ in Lake Mendota and $185 \mathrm{~h}$ in Knaack Lake) than either that observed for glucose (12 h in Lake Mendota) or previously reported for acetate $(0.22 \mathrm{~h}$ in Lake Mendota). The numbers of pectinolytic anaerobes varied seasonally in both sediments $\left(10^{2}-10^{5}\right.$ and $10^{3}-10^{5} \mathrm{ml}^{-1}$ in Knaack Lake and Lake Mendota, respectively), and were highest during the fall after sedimentation of algal blooms and/or leaf detritus. Clostridium butyricum was identified as a prevalent pectinolytic anaerobe in both lakes. In mono-culture pectin fermentations, $C$. butyricum produced methanol, $\mathrm{H}_{2} / \mathrm{CO}_{2}$, acetate, ethanol and butyrate; growth stopped in the presence of excess energy source when the $\mathrm{pH}$ fell to $4 \cdot 3$. In co-culture pectin fermentations of $C$. butyricum/Methanosarcina barkeri, $\mathrm{H}_{2} / \mathrm{CO}_{2}$, methanol and acetate were detected as intermediary metabolites, and pectin was completely degraded to $\mathrm{CH}_{4}$ and $\mathrm{CO}_{2}$, the $\mathrm{pH}$ remaining neutral. ${ }^{14} \mathrm{C}$-radiotracer analysis substantiated the simultaneous conversion of $\mathrm{H}_{2} / \mathrm{CO}_{2}$, methanol and acetate to $\mathrm{CH}_{4}$ by $M$. barkeri as these metabolites were generated from pectin hydrolysis by $C$. butyricum.
\end{abstract}

\section{INTRODUCTION}

Pectin is a polymer of galacturonic acid linked by $1,4-\beta$ bonds and methoxylated to a varying extent at the carboxyl moieties. Pectin is a component of photosynthetic biomass (Kertesz, 1951) and is found in the plant leaves and algal cell walls that are commonly deposited into freshwater lake sediments. Pectin can be adundant in cyanobacterial sheaths (Desikachary, 1959; Wolk, 1973) and green algal walls (Gooday, 1971; Green \& Jennings, 1967; Prescott, 1968; Sikes, 1978). Quantitative data on the total input of pectin into a lake ecosystem from algal blooms or plant detritus are not available. Nonetheless, pectin is undoubtedly decomposed by anaerobic micro-organisms in association with the annual sedimentation of plant litter and algal cells.

Ecological studies on microbial pectin degradation are scant and have generally been related to plant-microbe interactions in disease or symbiosis, or to crop and food spoilage. Our previous studies (Winfrey et al., 1977; Winfrey \& Zeikus, 1977, 1979a, b; Zeikus \& Winfrey, 1976) on the microbial ecology of anaerobic decomposition processes have characterized the metabolism of immediate methanogenic precursors in Knaack Lake and Lake Mendota, Wisconsin. The methanogenic population of Lake Mendota was characterized in a general way; it was composed primarily of $\mathrm{H}_{2} / \mathrm{CO}_{2}$-metabolizing Methanobacterium species and Methanosarcina barkeri which fermented $\mathrm{H}_{2} / \mathrm{CO}_{2}$, methanol and/or acetate (Weimer \& Zeikus, 1978 $a, b$; Zeikus \& Winfrey, 1976). Carbon input in these lake sediment ecosystems varies tremendously because Knaack Lake is a small meromictic lake that receives considerable litter from surrounding trees (Winfrey \& Zeikus, 1979 b), whereas in the deep portions of Lake Mendota the non-limnic contribution to the total 
photosynthate decomposed is negligible and cyanobacteria and green algae make up the greater part of the sedimented primary production (Fallon \& Brock, 1979).

Pectin was chosen as a model biopolymer for studies on anaerobic biomass decomposition because of its presence in sedimented organic matter of the lakes, its unique chemical structure (i.e. a methoxylated polysaccharide), its commercial availability as a ${ }^{14} \mathrm{C}$-tracer, and its described decomposition by pectinolytic, anaerobic bacteria (Avrova, 1975; Lund \& Brocklehurst, 1978; Miller \& Macmillan, 1970; Rexová-Benková \& Markovič, 1976). The purpose of the present paper was to characterize the decomposition of pectin and the anaerobic pectinolytic population in two freshwater lake sediments and to document the metabolic interactions between prevalent pectinolytic bacteria and other sediment bacteria that account for complete anaerobic mineralization of the polymer.

\section{METHODS}

Sites and sampling procedures. Lake Mendota is a moderately eutrophic, hard-water lake of glacial origin in southern Wisconsin, U.S.A. It covers about 3900 ha, has an average depth of about $12 \mathrm{~m}$ and a maximum depth of $24 \mathrm{~m}$, and is anaerobic below $10.5 \mathrm{~m}$ during stratification. Two sampling sites $(18$ and $24 \mathrm{~m}$ in the deepest portions of the lake) were studied. Knaack Lake is a eutrophic, meromictic lake in central Wisconsin and covers about 1.1 ha. Anaerobic sediment was obtained from the deepest portion of the lake $(22 \mathrm{~m})$.

Sediment samples were taken with an Eckman dredge. The overlying water was carefully removed and the upper 1-2 $\mathrm{cm}$ of the sediment was collected and transferred into $200 \mathrm{ml}$ glass bottles. These were gassed continuously with $\mathrm{O}_{2}$-free $\mathrm{N}_{2}$, anaerobically sealed with rubber stoppers and transferred to the laboratory in insulated chests (Zeikus \& Winfrey, 1976).

Growth media and culture methods. All media and culture methods were appropriate for stringent anaerobes (Zeikus, 1977; Zeikus et al., 1979). The low-phosphate buffered basal medium (LPBB medium) described by Zeikus et al. (1979) was used as a minimal medium for enumeration, enrichment and isolation of strains. Pectinolytic bacteria were enumerated and grown in LPBB medium containing $0.1 \%(\mathrm{w} / \mathrm{v})$ yeast extract and $0.5 \%(\mathrm{w} / \mathrm{v})$ pectin. Pectin solutions were prepared as described previously (Schink \& Zeikus, 1980). The pectin used had a degree of methoxylation of $66 \%$ and was a gift from Sunkist Growers (Corona, Calif., U.S.A.). Total heterotrophic bacteria were enumerated on LPBB medium containing $0.3 \%(\mathrm{w} / \mathrm{v})$ yeast extract, $1 \%(\mathrm{w} / \mathrm{v})$ tryptone, and $0.5 \%(\mathrm{w} / \mathrm{v})$ glucose. Methanogenic bacteria were enumerated on LPBB medium containing $0.05 \%$ yeast extract, with either a $\mathrm{H}_{2} / \mathrm{CO}_{2}(80: 20, \mathrm{v} / \mathrm{v})$ gas phase (for $\mathrm{H}_{2}$ oxidizers) or $0 \cdot 5 \%(\mathrm{v} / \mathrm{v})$ methanol and a $\mathrm{N}_{2} / \mathrm{CO}_{2}(95: 5)$ gas phase (for methanol oxidizers). Mixed culture studies with Methanosarcina barkeri strain UBS used the carbonate buffered basal medium (CBB medium) described by Zeikus \& Wolfe (1972). Strain UBS was isolated from Lake Mendota sediment (Zeikus \& Winfrey, 1976) and was growth adapted and cultivated for one year in CBB medium containing $0.5 \%(\mathrm{w} / \mathrm{v})$ acetate and $\mathrm{N}_{2} / \mathrm{CO}_{2}(95: 5)$ gas phase. All media were reduced with $0.05 \%(\mathrm{w} / \mathrm{v})$ sodium sulphide before inoculation. Except for co-culture experiments, all cultures used anaerobic culture tubes $(18 \times 142 \mathrm{~mm}$, Bellco Glass Co., Vineland, N.J., U.S.A.) sealed with black rubber stoppers and containing $10 \mathrm{ml}$ medium. Co-culture experiments were performed in $60 \mathrm{ml}$ Wheaton serum bottles (Millville, N.J.) closed with flanged black rubber bungs (Bellco) and aluminium crimp seals and containing $25 \mathrm{ml}$ medium. Enrichments and enumerations were incubated at $30^{\circ} \mathrm{C}$ without shaking, and co-culture experiments were incubated at $37^{\circ} \mathrm{C}$ on a rotary shaker /previous experiments had shown the optimum temperature for various metabolic processes of bacteria from the lake sediments to be in the range $30-40{ }^{\circ} \mathrm{C}$ (Winfrey \& Zeikus, $1979 b$ : Zeikus \& Winfrey, 1976)l. Growth was measured turbidimetrically at $660 \mathrm{~nm}$ in a Spectronic 20 colorimeter (Bausch and Lomb).

Enumeration procedures. Bacteria were enumerated in sediment samples by the three-tube most probable number (MPN) technique. Most probable numbers were calculated from standard tables (American Public Health Association, 1969) after 2-3 weeks incubation. Positive tubes for non-methanogens had an $A_{660}>0 \cdot 2$; those for methanogens produced $>1 \%(\mathrm{v} / \mathrm{v})$ methane in the culture headspace. Controls for enumeration of pectinolytic bacteria and methylotrophic methanogens used radioisotopic tracer analysis (see below) and were based on the production of ${ }^{14} \mathrm{CO}_{2}$ or ${ }^{14} \mathrm{CH}_{4}$ from labelled substrate.

Isolation of pectinolytic anaerobes. From the last positive tube in each enumeration series, pectinolytic bacteria were purified by streaking on to plates of the same pectin medium containing $2 \%(\mathrm{w} / \mathrm{v})$ agar in an anaerobic glove box. Single colonies were picked, purified by streaking, and then transferred to liquid medium for preparation of stock cultures. Purity was checked by uniformity of colonies on streak plates and by phase-contrast microscopy. For identification procedures, API 20A and 20E biochemical assay kits (Analytab Products, Plainview, N.Y., U.S.A.) were used.

Radioactive tracer techniques. Degradation of pectin in mud samples and in enumeration series was studied 
with $\left[\mathrm{U}^{-14} \mathrm{C}\right]$ pectin $\left(110 \mu \mathrm{Ci} \mathrm{mg}^{-1} ; 4 \mathrm{MBq} \mathrm{mg}^{-1}\right.$; ICN Pharmaceuticals Inc., Irvine. Calif.). $\left[{ }^{14} \mathrm{C} \mid \mathrm{Pectin}(0 \cdot 5-1\right.$ $\mu \mathrm{Ci}$ ) was added to the tubes from a stock solution $\left(55 \mu \mathrm{Ci} \mathrm{ml}{ }^{-1}\right)$ and the appearance of ${ }^{14} \mathrm{CO}_{2}$ and ${ }^{14} \mathrm{CH}_{4}$ measured in the gas phase by the combined gas chromatography and gas proportional counting procedures described by Nelson \& Zeikus (1974). The same analysis techniques were used for tracer studies with $\mid \mathrm{U}-{ }^{14} \mathrm{C} / \mathrm{glucose}$, $\left[{ }^{14} \mathrm{C} /\right.$ methanol, $\left[1-{ }^{14} \mathrm{C}\right.$ lacetate and $\left[2-{ }^{14} \mathrm{C}\right.$ lacetate (obtained from New England Nuclear Division, Boston, Mass., U.S.A.). The turnover time constant for $\left({ }^{14} \mathrm{C} /\right.$ pectin decomposition in sediment was determined by calculating the first-order rate of degradation to ${ }^{14} \mathrm{CH}_{4}\left(100 \%\right.$ biodegradation represents a recovery of $50 \%$ of the ${ }^{14} \mathrm{C}$-labelled substrate as ${ }^{14} \mathrm{CH}_{4}$ ).

Chemical analysis. Fatty acids and alcohols were analysed by flame ionization detection in a Packard 419 gas chromatograph as described by Zeikus et al. (1979). All gases were quantified by gas chromatography (Nelson \& Zeikus, 1974). Lactate was determined spectrophotometrically with $D$ - or L-lactate dehydrogenase according to Bergmeyer (1965). Reducing sugars in growth media were assayed by the dinitrophenylsalicylic acid method of Miller et al. (1960).

Chemicals. All chemicals were reagent grade and obtained from Sigma or Mallinckrodt, Inc. (Paris, Kentucky, U.S.A.). Agar, yeast extract and tryptone were from Difco; all gases were from Matheson (Joliet, Illinois, U.S.A.).

RESULTS

\section{Biodegradation of pectin}

The decomposition of pectin into $\mathrm{CO}_{2}$ and $\mathrm{CH}_{4}$ was compared in anoxic sediments collected at several times throughout the sampling years. Biodegradation was monitored while sediments were incubated at in situ temperature in the presence of trace amounts of radioactive pectin. Representative results for pectin degradation in sediments from Knaack Lake and Lake Mendota are shown in Fig. 1. Pectin appeared completely degraded after 3-4 $\mathrm{d}$ in Lake Mendota, whereas in Knaack Lake sediment, total observed degradation required 10-11 d. The differences in degradation patterns observed between the two lakes did not change significantly during the course of a sampling year. The turnover rate constants for pectin decomposition to $\mathrm{CH}_{4}$ in Lake Mendota and Knaack Lake were calculated to be 0.01 $\mathrm{h}^{-1}$ and $0.0054 \mathrm{~h}^{-1}$, respectively. For comparison, biodegradation of $\left[\mathrm{U}-{ }^{14} \mathrm{C}\right]$ glucose had a turnover rate constant of $0.083 \mathrm{~h}^{-1}$ in Lake Mendota sediment treated under the same experimental conditions. The optimal temperature for $\left[{ }^{14} \mathrm{C}\right]$ pectin degradation in both lake sediments was $30-40^{\circ} \mathrm{C}$.

\section{Enumeration of pectinolytic anaerobes}

The variation of total numbers of pectin-degrading anaerobic bacteria during the course of a sampling year in both lake sediments is shown in Fig. 2. The trend observed for increasing numbers from spring to fall was repeated in a second sampling year. In Lake Mendota, the minimum number of pectin-degrading bacteria varied between $10^{3}$ ( $\mathrm{ml}$ sediment $)^{-1}$ in early summer and $10^{5} \mathrm{ml}^{-1}$ in October/November. In Knaack Lake, minimum total numbers were about an order of magnitude lower than in Lake Mendota and varied between $10^{2} \mathrm{ml}^{-1}$ in May and $10^{5} \mathrm{ml}^{-1}$ in September/October. However, both lake sediments contained pectinolytic bacteria in numbers of the same order of magnitude when the results are compared on the basis of sediment dry matter. By comparison, the minimum numbers of pectinolytic anaerobes, total heterotrophic anaerobes, $\mathrm{H}_{2} / \mathrm{CO}_{2}$-metabolizing methanogens and methylotrophic methanogens per $\mathrm{ml}$ of Lake Mendota sediment throughout a two-year sampling period were $10^{3}-10^{5}, 10^{5}-10^{7}, 10^{3}-10^{4}$ and $10^{1}-10^{2}$, respectively. It is worth noting, however, that methylotrophic methanogens always existed as clumps of Methanosarcina, each containing several hundred cells.

\section{Isolation and characterization of the prevalent pectinolytic anaerobes}

The last positive enumeration tubes from numerous MPN determinations of pectinolytic anaerobes in both lake sediments always contained Gram-positive and Gram-negative rods of various sizes. Spore-forming cells as well as free, elliptical spores were present in all end dilution tubes. The cytological and physiological properties of six different strains of prevalent 


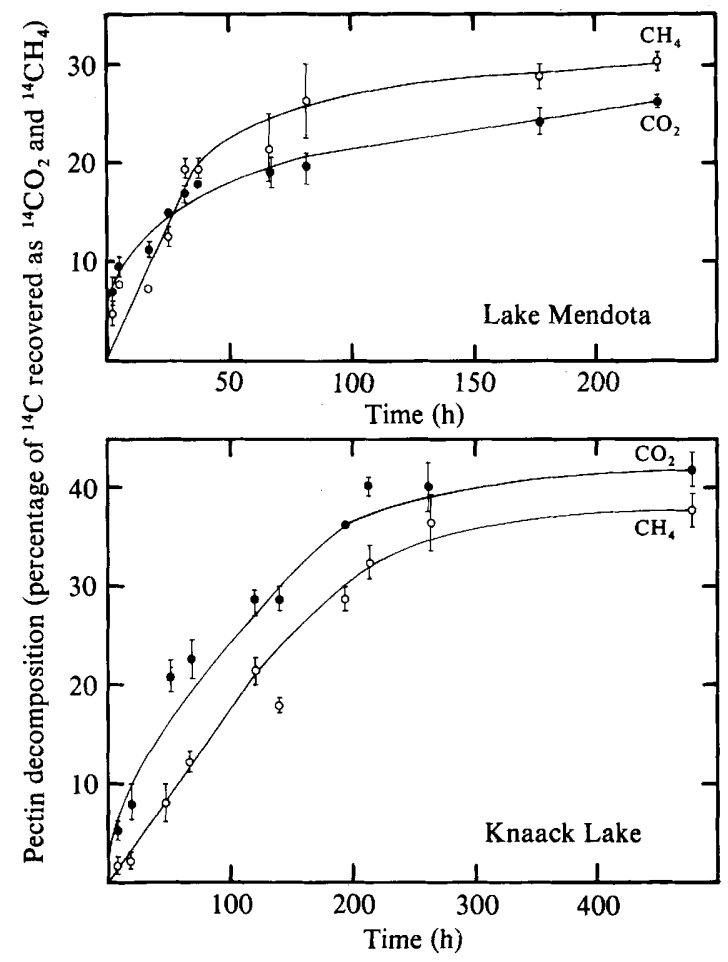

Fig. 1. Biodegradation of $\left[\mathrm{U}^{14} \mathrm{C}\right]$ pectin to ${ }^{14} \mathrm{CH}_{4}(\mathrm{O})$ and ${ }^{14} \mathrm{CO}_{2}(\mathrm{O})$ in anoxic lake sediments. Sediment $(10 \mathrm{ml})$ was incubated at in situ temperature $\left(15{ }^{\circ} \mathrm{C}\right.$ for Lake Mendota and $4{ }^{\circ} \mathrm{C}$ for $\mathrm{Knaack}$ Lake) in anaerobic culture tubes that contained $\mathrm{N}_{2}$ in the headspace and $1.0 \times 10^{6} \mathrm{~d} . \mathrm{p} . \mathrm{m} .{ }^{14} \mathrm{C}$ lpectin. Pectin was not decomposed in controls that contained $0.1 \%$ formalin. Standard error bars are shown for each point.

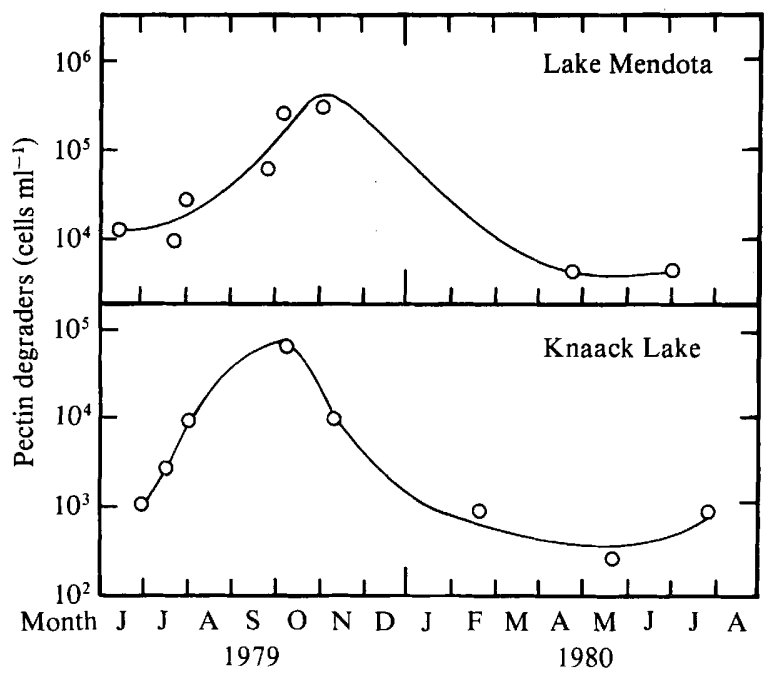

Fig. 2. Seasonal variation in total numbers of pectinolytic anaerobes in lake sediments.

pectinolytic bacteria isolated from lake sediments are shown in Table 1. The sporogenous strains MMP1, MMP2, MMP3 and KMP5 had similar properties; the asporogenous strains KMP3 and KMP4 differed from the other four - for example, they did not form significant 
Table 1. General microbiological features of prevalent pectinolytic anaerobes isolated from lake sediments

\begin{tabular}{|c|c|c|c|c|c|c|c|c|c|}
\hline \multirow[b]{3}{*}{ Strain } & \multirow[b]{3}{*}{ Lake } & \multicolumn{3}{|c|}{ Cell features } & \multirow{2}{*}{\multicolumn{5}{|c|}{$\begin{array}{l}\text { Pectin fermentation products* } \\
\text { (total } \mu \mathrm{mol} \text { per tube) }\end{array}$}} \\
\hline & & Size & & Gran & & & & & \\
\hline & & $(\mu \mathrm{m})$ & Spores & reaction & $\mathrm{H}_{2}$ & $\mathrm{MeOH}$ & $\mathrm{EtOH}$ & $\mathrm{Ac}$ & But \\
\hline MMP1 & Lake Mendota & $1.5 \times 6$ & + & + & 20 & 130 & 61 & 94 & 17 \\
\hline MMP2 & Lake Mendota & $1.2 \times 6$ & + & + & 58 & 122 & 70 & 100 & 18 \\
\hline MMP3 & Lake Mendota & $1.5 \times 6$ & + & + & 90 & 148 & 53 & 136 & 18 \\
\hline KMP3 & Knaack Lake & $0.7 \times 7$ & - & - & 14 & 100 & 74 & 30 & $<1$ \\
\hline KMP4 & Knaack Lake & $0.7 \times 7$ & - & - & 12 & 113 & 66 & 48 & $<1$ \\
\hline KMP5 & Knaack Lake & $1.5 \times 6$ & + & + & 143 & 140 & 57 & 217 & 28 \\
\hline
\end{tabular}

* Products were measured after growth for $24 \mathrm{~h}$ at $30^{\circ} \mathrm{C}$ on LPBB medium containing $0.1 \%$ yeast extract and $0.5 \%$ pectin. $\mathrm{MeOH}$, methanol; EtOH, ethanol; Ac, acetate; But, butyrate. Isopropanol, propanol, propionate, isobutyrate and lactate were not detectable (i.e. $<0.05 \mu \mathrm{mol}$ ).

Table 2. Relationship between energy source and fermentation products of Clostridium butyricum strain MMP3

\begin{tabular}{|c|c|c|c|c|c|c|c|c|}
\hline \multirow[b]{2}{*}{ Substrate } & \multirow{2}{*}{$\begin{array}{c}\text { Amount } \\
\text { consumed* } \\
(\mu \mathrm{mol})\end{array}$} & \multicolumn{7}{|c|}{ End products $\dagger$ (total $\mu$ mol per tube) } \\
\hline & & $\mathrm{H}_{2}$ & $\mathrm{MeOH}$ & $\mathrm{EtOH}$ & Ac & But & Lac & $\mathrm{CO}_{2}$ \\
\hline Glucose & 244 & 118 & $<0.05$ & 23 & 80 & 158 & 8 & 410 \\
\hline Polygalacturonic acid & 112 & 123 & $<0.05$ & 18 & 170 & 15 & $<0.5$ & 224 \\
\hline Pectin & 108 & 160 & 152 & 21 & 158 & 26 & $<0.5$ & 197 \\
\hline
\end{tabular}

* As determined by analysis of total reducing sugars (Miller et al., 1960) before and after growth. Culture fluid $(0.5 \mathrm{ml})$ was acidified with $5 \mathrm{M}-\mathrm{H}_{2} \mathrm{SO}_{4}(40 \mu \mathrm{l})$, boiled for $2 \mathrm{~h}$ and neutralized with $\mathrm{NaOH}$ prior to analysis for polygalacturonic acid or pectin.

+ Products were measured after growth for $24 \mathrm{~h}$ at $30^{\circ} \mathrm{C}$ on LPBB medium containing $0.1 \%$ yeast extract and $0.5 \%$ substrate. $\mathrm{MeOH}$, methanol; EtOH, ethanol; Ac, acetate; But, butyrate; Lac, lactate.

amounts of butyrate when grown on glucose or pectin as energy source. None of the strains produced methanol from glucose. Strain MMP3 was chosen as a representative of the pectinolytic Clostridium species that prevailed in both lake sediments. Biochemical and physiological tests established that strain MMP3 was Clostridium butyricum according to the criteria of Buchanan \& Gibbons (1974). Strain MMP3 fermented starch, mannan and pectin but not cellulose, xylan or arabinogalactan. It did not liquefy gelatin, nor reduce $\mathrm{SO}_{4}^{2-}$ and $\mathrm{NO}_{3}^{-}$.

The fermentation products formed after growth of strain MMP3 on glucose, polygalacturonic acid or pectin are shown in Table 2. The main products of glucose fermentation were butyrate, acetate, $\mathrm{H}_{2}$ and $\mathrm{CO}_{2}$, with traces of ethanol and L-lactate. As compared with growth on glucose, after growth on the more oxidized substrates, polygalacturonic acid and pectin, only about half the amount of substrate was consumed, acetate was formed in higher amounts, butyrate in lower amounts, and lactate was not detectable. The average values observed for final cell density $\left(A_{660}\right)$ after growth on glucose and on pectin or polygalacturonate were 1.05 and 0.75 , respectively; the final $\mathrm{pH}$ was 4.3 in each case.

A time course for a typical pectin fermentation of C. butyricum is shown in Fig. 3. All the end products, except for butyrate, which was formed late in growth, were formed in relation to the increase in growth that paralleled pectin consumption. The products formed at the end of growth accounted for a balanced fermentation: the values for carbon recovery and oxidation/reduction $(\mathrm{O} / \mathrm{R})$ balance were $101.4 \%$ and 1.05 , respectively. The following 


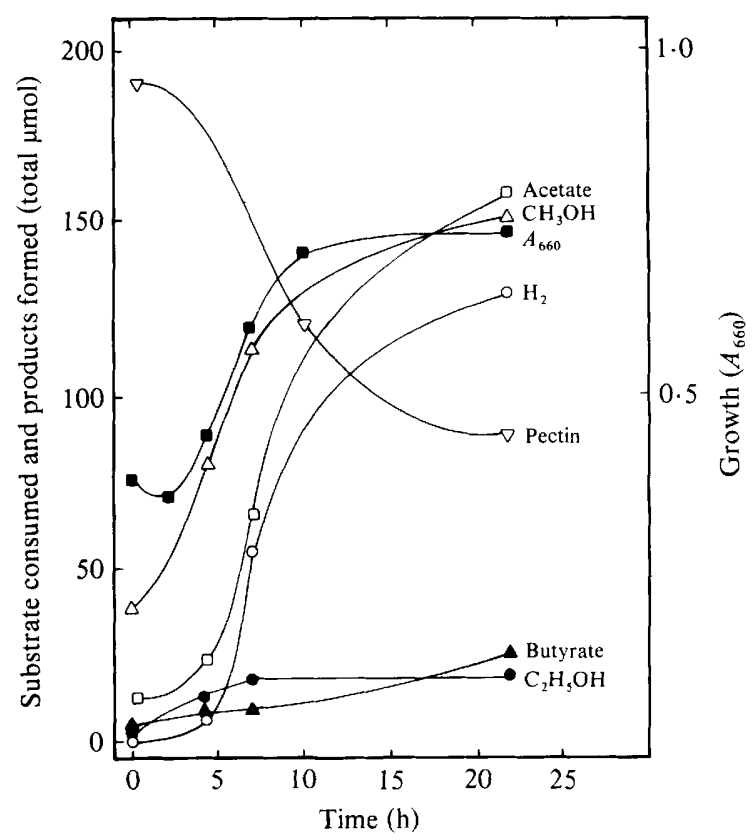

Fig. 3. Pectin fermentation time course for mono-cultures of $C$. butyricum strain MMP3. Anaerobic culture tubes contained $10 \mathrm{ml}$ LPBB medium, $0.1 \%$ yeast extract, $0.5 \%$ pectin, $\mathrm{N}_{2} / \mathrm{CO}_{2}$ in the headspace and a $0.1 \mathrm{ml}$ inoculum that had been grown on the same medium. The incubation temperature was $30^{\circ} \mathrm{C} . \mathbf{\square}$, Growth $\left(A_{660}\right) ; \nabla$, pectin; $\square$, acetate: $\triangle$ methanol; $\mathrm{O}, \mathrm{H}_{2} ; \Delta$, butyrate: - ethanol.

balanced equation describes the stoichiometric relation observed for pectin fermentation (in total $\mu \mathrm{mol})$ :

$108 \mathrm{C}_{6.7} \mathrm{H}_{12} \mathrm{O}_{6} \rightarrow 160 \mathrm{H}_{2}+152 \mathrm{CH}_{3} \mathrm{OH}+21 \mathrm{CH}_{3} \mathrm{CH}_{2} \mathrm{OH}+158 \mathrm{CH}_{3} \mathrm{COOH}+26 \mathrm{CH}_{3} \mathrm{CH}_{2} \mathrm{CH}_{2} \mathrm{COOH}+197 \mathrm{CO}_{2}$

Methanol was formed in a ratio of $1 \mathrm{~mol}$ per mol methoxyl groups in the added pectin.

In order to investigate the metabolic basis for the cessation of growth of $C$. butyricum in the presence of excess energy source, the effect of different end products on the growth of strain MMP3 was examined (results not shown). In these experiments, end products were added to early/mid-exponential phase cultures at concentrations that equalled or exceeded the fermentation product concentration at the end of growth. Addition of $\mathrm{H}_{2}$ did not inhibit growth even at concentrations up to $1 \mathrm{~atm}$. Normal end product concentrations of methanol (i.e. $0.05 \%$ ) did not influence growth rate or yield but at $0.2 \%$ methanol, growth yield was lowered by $14 \%$. Addition of end product concentrations of acetate $(20 \mathrm{~mm}$, as sodium acetate) increased the growth rate and yield, whereas addition of $20 \mathrm{~mm}$-sodium butyrate had no effect. High $\mathrm{H}^{+}$concentration had the greatest effect on growth: upon addition of $\mathrm{HCl}$ to change the culture $\mathrm{pH}$ to $4 \cdot 5$, growth ceased. Growth was not influenced in control tubes that contained $2 \cdot 0 \% \mathrm{NaCl}$.

\section{Complete decomposition of pectin in methanogenic co-culture}

In order to examine the metabolic interactions associated with anaerobic mineralization of pectin to $\mathrm{CH}_{4}$, a co-culture comprised of Methanosarcina barkeri strain UBS and $C$. butyricum strain MMP3 was established. Strain UBS was precultivated on $0.5 \%$ sodium acetate in CBB medium at $37^{\circ} \mathrm{C}$. An inoculum $(0.5 \mathrm{ml})$ of strain MMP3 grown on pectin and pectin $\left(1.2 \mathrm{mg} \mathrm{ml}^{-1}\right)$ were added to an acetate-depleted culture of strain UBS. This procedure established a stable co-culture of the two organisms that continued to degrade 


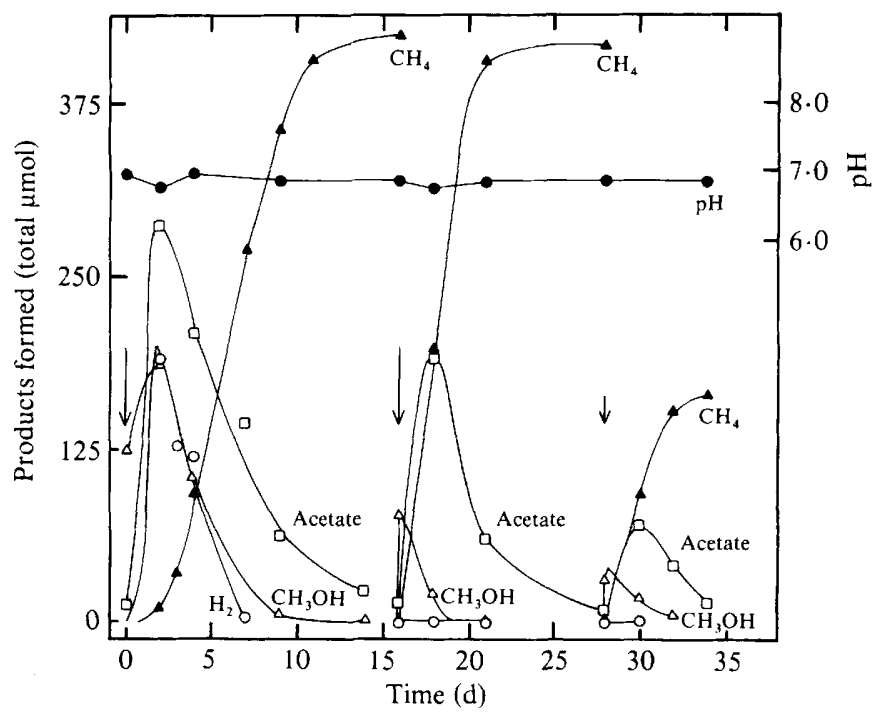

Fig. 4. Pectin fermentation time course for co-cultures comprised of $C$. butyricum strain MMP 3 and $M$. barkeri strain UBS. Anaerobic serum vials contained $25 \mathrm{ml} \mathrm{LPBB}$ medium and a $\mathrm{N}_{2}$ gas phase. Where indicated, either $30 \mathrm{mg}$ (large arrow) or $10 \mathrm{mg}$ (small arrow) pectin was added. Cultures were incubated at $37^{\circ} \mathrm{C}$ with shaking. $\mathrm{OH} ; \triangle, \mathrm{CH}_{4} ; \square$, acetate; $\triangle$, methanol; $\mathrm{O}, \mathrm{H}_{2}$.

pectin and make $\mathrm{CH}_{4}$ upon continued addition of pectin or culture transfer into LPBB medium that contained pectin as the sole energy source. After 3 months of cultivation by semicontinuous addition of pectin, the co-culture was transferred to LPBB medium containing $1.2 \mathrm{mg}_{\text {pectin }} \mathrm{ml}^{-1}$ and the relationship of substrate consumption and end product formation was examined with time (Fig. 4). Methanol, acetate and $\mathrm{H}_{2}$ appeared as the primary oxidizable end products of pectin degradation by the co-culture. These substrates were simultaneously decomposed by the co-culture during the next $15 \mathrm{~d}$. After the addition of an equivalent amount of pectin on day 16, methanol and acetate appeared again as methanogenic intermediates, but in smaller amounts than before. Notably, $\mathrm{H}_{2}$ was not detectable and the rate of pectin decomposition (as inferred from the rate of methane formation) increased over that observed during the first feeding. When pectin was added on day 28 in an amount equivalent to one-third of the initial starting concentration, pectin was completely degraded in about $6 \mathrm{~d}$ and the final $\mathrm{CH}_{4}$ yield was about one-third of the amount formed during the previous feedings.

The data obtained for pectin fermentation following the first two feedings were subjected to mass balance analysis according to the following theoretical equations of Tarvin \& Buswell (1934):

A. General equation for a balanced methanogenic fermentation

$$
\mathrm{C}_{n} \mathrm{H}_{a} \mathrm{O}_{b}+\left[n-\frac{a}{4}-\frac{b}{2}\right] \mathrm{H}_{2} \mathrm{O} \rightarrow\left[\frac{n}{2}+\frac{a}{8}-\frac{b}{4}\right] \mathrm{CH}_{4}+\left[\frac{n}{2}-\frac{a}{8}+\frac{b}{4}\right] \mathrm{CO}_{2}
$$

B. Balanced equation for methanogenic fermentation of pectin

$$
\mathrm{C}_{6 \cdot 7} \mathrm{H}_{12} \mathrm{O}_{6}+0.67 \mathrm{H}_{2} \mathrm{O} \rightarrow 3.32 \mathrm{CH}_{4}+3.32 \mathrm{CO}_{2}
$$

The following experimental equation was obtained at the end of the feeding experiments:

$$
160 \mu \mathrm{mol} \text { pectin } \rightarrow 475 \mu \mathrm{mol} \mathrm{CH} 4+480 \mu \mathrm{mol} \mathrm{CO} \mathrm{CO}_{2}+7.5 \mathrm{mg} \text { cells }
$$

Thus, the results obtained account for a balanced redox fermentation. The values obtained for $\mathrm{CH}_{4}(2.97)$ and $\mathrm{CO}_{2}(3.0)$ per mol pectin fermented were lower than predicted in equation $\mathrm{B}$ as a result of the cell biomass synthesized from pectin. 


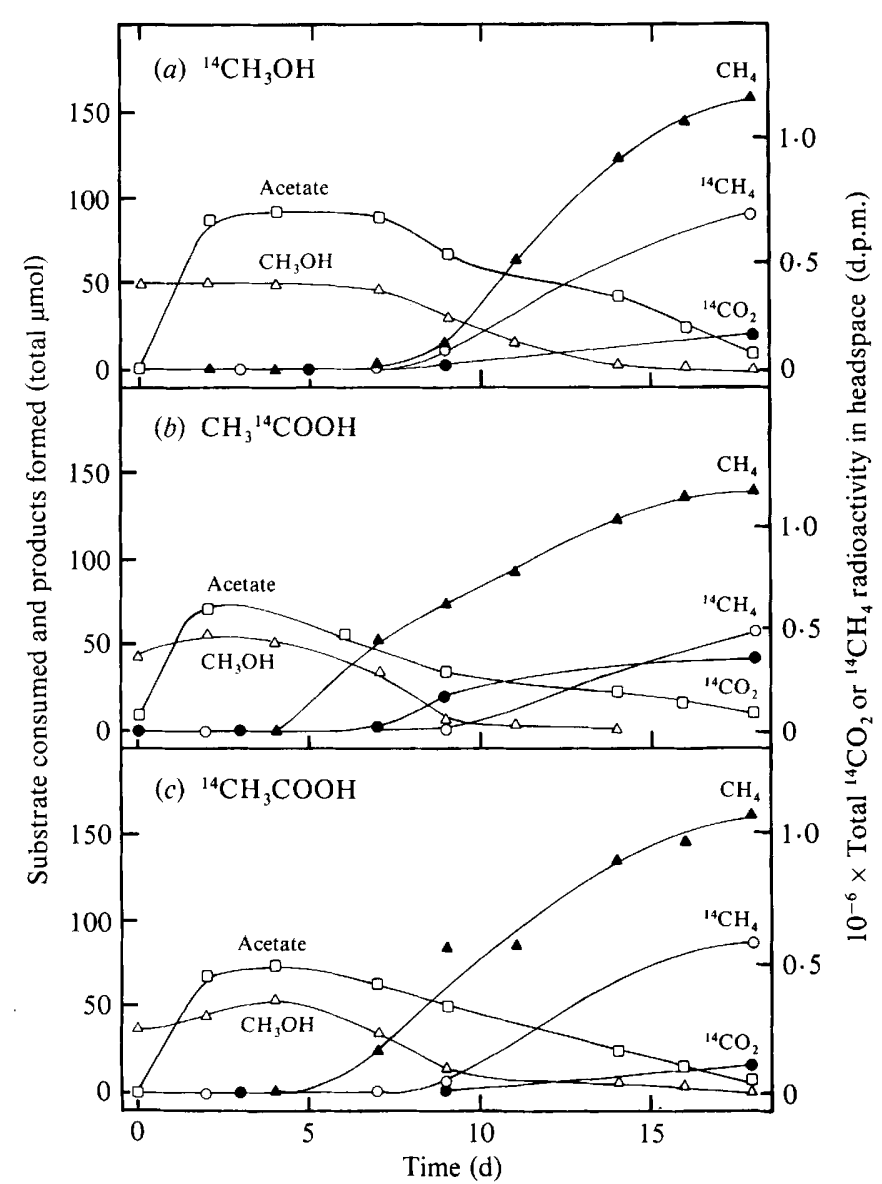

Fig. $5 .{ }^{14} \mathrm{C}$-Radiotracer analysis of methanogenic precursors during pectin fermentation by co-cultures of C. butyricum strain MMP3 and M. barkeri strain UBS. On day 2 of the time course $1 \times 10^{6}$ d.p.m. of (a) ${ }^{14} \mathrm{CH}_{3} \mathrm{OH},($ b $) ~ 11-{ }^{14} \mathrm{C}$ lacetate or $(c) 12-{ }^{14} \mathrm{C}$ lacetate was added. Medium contents and culture conditions were the same as employed for initiation of the time course experiments in Fig. 4. $\square$, Acetate; $\triangle$, methanol; $\triangle, \mathrm{CH}_{4} ; \mathrm{O} .{ }^{14} \mathrm{CH}_{4} ;{ }^{14} \mathrm{CO}_{2}$.

Radiotracer experiments with ${ }^{14} \mathrm{C}$-labelled acetate and methanol were performed to further substantiate the simultaneous transformation of methanogenic intermediates by the co-culture. These experiments were designed in an identical manner to that described above for initiation of a co-culture pectin fermentation time course, except that replicate experimental tubes contained either ${ }^{14} \mathrm{CH}_{3} \mathrm{OH},{ }^{14} \mathrm{CH}_{3} \mathrm{COOH}$ or $\mathrm{CH}_{3}{ }^{14} \mathrm{COOH}$. The results in Fig. 5 show that ${ }^{14} \mathrm{C}$ atoms in methanol and $\mathrm{C}-2$ labelled acetate were simultaneously transferred to methane during simultaneous consumption of methanol and acetate by the co-culture. The origin of ${ }^{14} \mathrm{C}$-methane from the $\mathrm{C}$-1 labelled acetate was probably from the $\mathrm{H}_{2}$-mediated reduction of ${ }^{14} \mathrm{CO}_{2}$ generated from the acetate, because it was formed after the appearance of labelled $\mathrm{CO}_{2}$.

\section{DISCUSSION}

Our results show that pectin is readily mineralized to $\mathrm{CH}_{4}$ and $\mathrm{CO}_{2}$ in anoxic sediments of Lake Mendota and Knaack Lake. In Lake Mendota the biodegradation of pectin was more rapid than that reported for cellulose (Nelson \& Zeikus, 1974) and lignin (Hackett et al., 1977), which appears totally recalcitrant to anaerobic mineralization at neutral $\mathrm{pH}$ (Zeikus, 
1981). Nonetheless, the observed turnover time for decomposition of pectin to methane in Lake Mendota $(100 \mathrm{~h}$ ) was considerably longer than for either glucose $(12 \mathrm{~h})$, a soluble substrate metabolized by non-methanogens, or for acetate $(0.22 \mathrm{~h})$, the major immediate methane precursor (Winfrey \& Zeikus, 1979a). These results support the general hypothesis (Wetzel, 1975; Zeikus, 1977, 1980) that degradation of biopolymers is a rate-limiting step in anaerobic digestion of biomass. Native pectin associated with biomass (in leaves or algal walls) may be degraded at a lower rate than that demonstrated here for isolated pectin. Otsuki \& Hanya (1972) demonstrated that degradation of intact cyanobacteria in anoxic sediments proceeded much more slowly: after $60 \mathrm{~d}$ incubation, only $20 \%$ of the cells were mineralized, with $50 \%$ remaining particulate and $30 \%$ solubilized to dissolved organic matter. The reasons for differences in the rate of pectin mineralization in Knaack Lake and Lake Mendota are not known. The lower rate of biodegradation in Knaack Lake may be related to environmental differences such as lower in situ temperature and $\mathrm{pH}$ (Winfrey \& Zeikus, $1979 b$; Zeikus \& Winfrey, 1976).

The number of pectin fermenting bacteria varied seasonally by two orders of magnitude in both lake sediments studied. The highest numbers of pectinolytic anaerobes were found in the fall at a time after the main input of pectinous substrates such as sedimented leaves of higher plants and dead algal blooms. Thus, the pectinolytic clostridia isolated appear active in their environment and express their metabolic potential in response to the presence of substrate. The finding that Clostridium species are prevalent pectinolytic anaerobes in Lake Mendota is in agreement with the results of Monolongoski \& Klug (1976), who identified clostridia as the numerically dominant fermentative micro-organism in Wintergreen Lake, Michigan. Notably, both Clostridium species and unidentified, Gram-negative asporogenous rods were prevalent pectin degraders in Knaack Lake. These studies extend the known niche for pectinolytic clostridia and $C$. butyricum to include anoxic freshwater sediments. The numerical significance of Clostridium species as important agents of pectinolysis has also been established in the retting of hemp (Avrova, 1975), the soft rot of potatoes (Lund \& Brocklehurst, 1978) and the wetwood of living trees (Schink et al., 1981).

The data suggest that the anaerobic microbial food chain required to degrade completely a biopolymer such as pectin may consist of only two species. This may appear surprising, but it agrees with previous artificial studies (Winter \& Wolfe, 1979) that demonstrated complete fermentation of fructose to $\mathrm{CH}_{4}$ and $\mathrm{CO}_{2}$ by a mixed culture of Acetobacterium woodii and Methanosarcina barkeri. The association of $M$. barkeri and $C$. butyricum as prevalent methylotrophic methanogen and pectinolytic anaerobe in lake sediment may derive from a natural metabolic consequence. We recently showed that a wide variety of aerobic, facultative and obligately anaerobic bacteria produced but did not consume methanol during growth on pectin (Schink \& Zeikus, 1980). Hence, the presence of pectin biodegradation in anaerobic ecosystems establishes a niche for methylotrophs. In the absence of excess electron acceptors (e.g. $\mathrm{O}_{2}, \mathrm{NO}_{3}^{-}$or $\mathrm{SO}_{4}^{2-}$ ), methanol consumption by methanogens may be the favoured route of biodegradation that eliminates potential microbial toxicity due to methanol accumulation in lake sediments. Positive cell-cell interactions involving methylotrophic bacteria have been reported previously for aerobic species. For example, Wilkinson et al. (1974) demonstrated that growth of aerobic mixed cultures on methane was enhanced as the result of removal of toxic methanol by a Hyphomicrobium species which was produced by a methane-oxidizing Pseudomonas species.

Analysis of metabolic interactions between $C$. butyricum and $M$. barkeri during growth on pectin supports and further extends knowledge on the biological role of methanogens during the anaerobic digestion of organic matter in nature. As a consequence of their metabolic features, methanogens influence the decomposition of organic matter by hydrolytic anaerobes by removing toxic metabolites such as $\mathrm{H}^{+}, \mathrm{H}_{2}$ and methanol; by directing electron flow to limited reduced end products; by increasing growth rate and yields; and by supplying essential growth factors (Zeikus, 1977, 1980). The most important bioregulatory function of 
the methanogen in the pectin fermentation was $\mathrm{H}^{+}$consumption, for the cessation of growth of $C$. butyricum in mono-culture was due to accumulation of $\mathrm{H}^{+}$and not $\mathrm{H}_{2}$, methanol or acetate. $\mathrm{H}_{2}$ was not a significant metabolic effector for growth of $C$. butyricum. $\mathrm{H}_{2}$-producing anaerobes vary considerably as to whether $\mathrm{H}_{2}$ inhibits growth, and this is a reflection of species differences in enzymic activities that direct electron flow within cells (Ben-Bassat et al., 1981; Lamed \& Zeikus, 1980). Thus, C. butyricum resembles C. thermocellum (Weimer \& Zeikus, 1977), and not $C$. cellobioparum, whose growth is inhibited by low partial pressures of $\mathrm{H}_{2}$ (Chung, 1976). Although C. butyricum stoichiometrically converted all the methoxyl groups of pectin to methanol, in mono-culture the final methanol concentration was not toxic to growth. The stimulation of growth observed by addition of acetate to $C$. butyricum mono-cultures was probably a consequence of circumventing the need to generate this intermediate as an electron acceptor for butyrate synthesis. In co-culture, 'normal' electron flow of $C$. butyricum was directed by $M$. barkeri to $\mathrm{H}_{2}$ in lieu of ethanol or butyrate. This alteration of electron flow when coupled to methanogenesis enabled $C$ butyricum to generate more energy in co-culture than in mono-culture from an equivalent amount of substrate metabolized. It should be noted that in the absence of yeast extract in culture medium, $C$. butyricum grows very slowly on pectin or other carbohydrates. However, growth in co-culture with $M$. barkeri was rapid even in the absence of yeast extract. This observation suggests that this methanogen may supply limiting growth factors to C. butyricum.

Our data support the hypothesis of Weimer \& Zeikus $(1978 a, b)$ that $M$. barkeri is capable of simultaneous metabolism of $\mathrm{H}_{2} / \mathrm{CO}_{2}$, acetate and methanol. This was confirmed by both analysis of immediate methanogenic precursor concentrations and ${ }^{14} \mathrm{C}$-tracer studies during co-culture fermentation of pectin. This is contrary to other interpretations of the metabolism of Methanosarcina strains, which suggested that $\mathrm{H}_{2} / \mathrm{CO}_{2}$ or methanol catabolite repressed acetate utilization (Smith \& Mah, 1978). Our data clearly showed that the preference for methanogenic substrate utilization by $M$. barkeri is in the order $\mathrm{H}_{2} / \mathrm{CO}_{2}>$ methanol $>$ acetate. Thus, the preferential utilization of $\mathrm{H}_{2} / \mathrm{CO}_{2}$ over acetate supports the previous conclusion of Winter \& Wolfe (1979) but it does not imply that $\mathrm{H}_{2} / \mathrm{CO}_{2}$ and acetate are not simultaneously converted to $\mathrm{CH}_{4}$. Past studies on the metabolism of $M$. barkeri have been controversial, largely because of difficulties associated with growth of the organism and the enigmatic requirement for very long culture adaptation periods to obtain significant growth on acetate as an energy source (Weimer \& Zeikus, 1978a; Zeikus et al., 1975). However, significant simultaneous metabolism of acetate, $\mathrm{H}_{2} / \mathrm{CO}_{2}$ and methanol by acetate-adapted strains of $M$. barkeri requires control of individual substrate concentration in the medium. It is obvious that during co-culture growth on pectin the concentration of methanogenic substrates is limited by the rate of pectin conversion and the rate of intermediary metabolite consumption.

This research was supported by the College of Agricultural and Life Sciences, University of Wisconsin, by a grant from the Ecological Research Division of the Department of Energy, and by grant DEB 7824071 from the National Science Foundation. Bernhard Schink was supported by a fellowship from the Deutsche Forschungsgemeinschaft. The authors thank Tom Phelps for experimental advice and assistance, and acknowledge Gina Cuccia for technical aid. Access to boats and sampling equipment of Dr T. D. Brock and the Limnology Department, University of Wisconsin, is appreciated.

\section{REFERENCES}

American Public Health Association (1969). Standard Methods for the Examination of Water and Wastewater Including Bottom Sediments and Sludge, pp. 604-609. New York: American Public Health Association.

Avrova, N. P. (1975). Synthesis of pectolytic enzymes by Clostridium felsineum and their hydrolysis of the pectin substances of flax straw. Applied Biochemistry and Microbiology 11, 736-741.
Ben-Bassat, A., Lamed, R. J. \& Zeikus, J. G. (1981). Ethanol production by thermophilic bacteria: metabolic control of end product formation in Thermoanaerobium brockii. Journal of Bacteriology 146, 192-199.

BERGMEYER, H. U. (editor) (1965). Methods of Enzymatic Analysis. Weinheim, Germany: Verlag Chemie.

Buchanan, R. E. \& Gibbons, N. E. (editors) (1974). 
Bergey's Manual of Determinative Bacteriology, 8th edn. Baltimore: Williams \& Wilkins.

Chung, K. T. (1976). Inhibitory effects of $\mathrm{H}_{2}$ on growth of Clostridium cellobioparum. Applied and Environmental Microbiology 31, 342-348.

Desikachary, T. V. (1959). Cyanophyta, p. 53. New Delhi: Indian Council of Agricultural Research.

Fallon, R. D. \& BRoCk, T. D. (1979). Decomposition of blue-green algal (cyanobacterial) blooms in Lake Mendota, Wisconsin. Applied and Environmental Microbiology 37, 820-830.

Gooday, G. W. (1971). A biochemical and autoradiographic study of the role of the Golgi bodies in thecal formation in Platymonas tetrathele. Journal of Experimental Botany 23, 959-971.

Green, J. C. \& Jennings, D. H. (1967). A physical and chemical investigation of the scales produced by the Golgi apparatus within and found on the surface of the cells of Chrysochromulina cheiton Parke et Manton. Journal of Experimental Botany 18, 359-370.

HaCketT, W. F., Connors, W. J., Kirk, T. K. \& ZEIKUS, J. G. (1977). Microbial decomposition of synthetic ${ }^{14} \mathrm{C}$-labeled lignins in nature: lignin biodegradation in a variety of natural materials. Applied and Environmental Microbiology 33, 43-51.

Kertesz, Z. J. (1951). The Pectic Substances. New York: Interscience Publishers.

LAMED, R. J. \& Zeikus, J. G. (1980). Ethanol production by thermophilic bacteria: relationship between fermentation product yields and catabolic enzyme activities in Clostridium thermocellum and Thermoanaerobium brockii. Journal of Bacteriology 144. 569-578.

Lund, B. M. \& Brocklehurst, T. E. (1978). Pectic enzymes of pigmented strains of Clostridium. Journal of General Microbiology 104, 59-66.

Miller, L. \& Macmillan, J. D. (1970). Mode of action of pectic enzymes. II. Further purification of exopolygalacturonate lyase and pectin esterase from Clostridium multifermentans. Journal of Bacteriology 102, 72-78.

Miller, G. L., Blum, O. R., Glennon, W. E. \& Burton, A. L. (1960). Measurement of carboxymethycellulase activity. Analytical Biochemistry 1, 127-132.

Monolongoski, J. J. \& Klug, M. J. (1976). Characterization of anaerobic heterotrophic bacteria isolated from freshwater lake sediments. Applied and Environmental Microbiology 31, 83-90.

Nelson, D. R. \& Zeikus, J. G. (1974). Rapid method for the radioisotopic analysis of gaseous end products of anaerobic metabolism. Applied Microbiology 28 258-261.

Otsuki, A. \& Hanya, T. (1972). Production of dissolved organic matter from dead green algal cells. II. Anaerobic microbial decomposition. Limnology and Oceanography 17, 258-269.

PrescotT, G. W. (1968). The Algae: a Review, p. 8, p. 39. Boston, Mass.: Houghton Mifflin Co.

Rexová-Benková, L. \& Markovič, O. (1976). Pectic enzymes. Advances in Carbohydrate Chemistry and Biochemistry 33, 323-385.

Schink, B. \& ZeIKUS, J. G. (1980). Microbial methanol formation: a major end product of pectin metabolism. Current Microbiology 4, 387-390.
Schink, B., WaRd, J. C. \& Zeikus, J. G. (1981). Microbiology of wetwood: role of anaerobic bacterial populations in living trees. Journal of General Microbiology 123, 313-322.

SiKes, C. S. (1978). Calcification and cation sorption of Cladophora glomerata (Chlorophyta). Journal of Phycology 14, 325-329.

SMITH, M. R. \& MAH, R. A. (1978). Growth and methanogenesis by Methanosarcina strain 227 on acetate and methanol. Applied and Environmental Microbiology 36, 870-879.

TARvin, D. \& Buswell, A. M. (1934). The methane formation of organic acids and carbohydrates. Journal of the American Chemical Society 56. 1751-1755.

WeIMER, P. J. \& ZeIKUS, J. G. (1977). Fermentation of cellulose and cellobiose by Clostridium thermocellum in the absence and presence of Methanobacterium thermoautotrophicum. Applied and Environmental Microbiology 33, 289-292.

Weimer, P. J. \& Zeikus, J. G. (1978a). Acetate metabolism of Methanosarcina barkeri. Archives of Microbiology 119, 175-182.

Weimer, P. J. \& Zeikus, J. G. (1978b). One carbon metabolism in methanogenic bacteria: cellular characterization and growth of Methanosarcina barkeri. Archives of Microbiology 119, 49-57.

Wetzel, R. G. (1975). Limnology, pp. 562-564. Philadelphia: W. B. Saunders Co.

Wilkinson, T. G., Topiwala, H. H. \& Hamer, G. (1974). Interactions in a mixed bacterial culture growing on methane in continuous culture. Biotechnology and Bioengineering 16, 41-47.

Winfrey, M. R. \& ZeIKUS, J. G. (1977). Effect of sulfate on carbon and electron flow during microbial methanogenesis in freshwater sediments. Applied and Environmental Microbiology 33, 215-221.

Winfrey, M. R. \& ZeIKUS, J. G. (1979 a). Anaerobic metabolism of immediate methane precursors in Lake Mendota. Applied and Environmental Microbiology 37, 244-253.

WinfReY, M. R. \& Zeikus, J. G. (1979 b). Microbial methanogenesis and acetate metabolism in a meromictic lake. Applied and Environmental Microbiology 37, 213-221.

Winfrey, M. R., Nelson, D. R., Klevickis, S. C. \& ZeIKUS, J. G. (1977). Association of hydrogen metabolism with methanogenesis in Lake Mendota sediments. Applied and Environmental Microbiology 33, 312-318.

WINTER, J. \& Wolfe, R. S. (1979). Complete degradation of carbohydrate to carbon dioxide and methane by syntrophic cultures of Acetobacterium woodii and Methanosarcina barkeri. Archives of Microbiology 121, 97-102.

Wolk, P. (1973). Physiology and cytological chemistry of blue-green algae. Bacteriological Reviews 37, 32-101.

ZeIKUS, J. G. (1977). The biology of methanogenic bacteria. Bacteriological Reviews 41, 514-541.

ZeIKUS, J. G. (1980). Microbial populations in digestors. In First International Symposium on Anaerobic Digestion, pp. 61-87. Edited by D. A. Stafford. Cardiff: A. D. Scientific Press.

ZeIKuS, J. G. (1981). Lignin metabolism and the carbon cycle: polymer biosynthesis, biodegradation 
and environmental recalcitrance. Advances in Microbial Ecology 5, 1-42.

ZEIKUS, J. G. \& WINFREY, M. R. (1976). Temperature limitation of methanogenesis in aquatic sediments. Applied and Environmental Microbiology 31, 99107.

ZeIKus, J. G. \& Wolfe, R. S. (1972). Methanobacterium thermoautotrophicum sp. nov., an anaerobic, autotrophic, extreme thermophile. Journal of Bacteriology 109, 707-713.
Zeikus, J. G., Weimer, P. H., Nelson, P. R. \& DANIELS, L. (1975). Bacterial methanogenesis: acetate as a methane precursor in pure culture. Archives of Microbiology 104, 129-134.

Zeikus, J. G., Hegge, P. W. \& Anderson, M. A. (1979). Thermoanaerobium brockii gen. nov. and sp. nov., a new chemoorganotrophic, caldoactive, anaerobic bacterium. Archives of Microbiology 122 , 41-48. 